\title{
A NOVEL MODEL INTEGRATING THE PROCESSES OF SELECTION AND BEHAVIORAL EVALUATION OF SUPPLIERS IN A SUPPLY CHAIN THROUGH ANALYTICAL HIERARCHY PROCESS (AHP)
}

\author{
Mohamed Khendek \\ Department of Business Administration \\ IIUM University, Jalan Gombak \\ 53100 Kuala Lumpur, Malaysia. \\ Moussa Larbani* \\ Department of Business Administration \\ IIUM University, Jalan Gombak \\ 53100 Kuala Lumpur, Malaysia. \\ Email:
}

\begin{abstract}
Suppliers' selection and development play a key role in supply chain success and the well enrolment of the overall business. To this end, extensive researches focused on developing methods to sustain supplier selection have been used assortments of factors as criteria for supplier selection. These criteria are linked to the nature of products, their targeted market and applicability. Nevertheless, relatively little work has been undertaken behavioral aspects for selection and evaluation to develop systematic and dynamic models, taking into account the uncertainty in business environment. This paper presents an application of analytic hierarchy process (AHP) in a multi-period dynamic selection and evaluation of suppliers in a supply chain. The paper describes the exemplary steps of supplier selection and evaluation process and proposes a detailed example to illustrate the introduced model using five major criteria: Quality, Delivery, Cost, Manufacturing Capabilities and Management. Including functional and behavioral aspects, the result of this study shows that such an AHP application can assist managers to effectively improve supplier selection and evaluation process even under complex economic conditions.
\end{abstract}

Keywords: Analytic hierarchy process; Multi-criteria decision-making; Supplier selection and evaluation; behavioral aspects.

\section{Introduction}

The term supply chain management was originally used in the early 1980s (Oliver and Webber, 1992). It referred to the management of materials, information, finances and it consists of all links from suppliers to customers of a product. Harland et al. (1999) indicates that the evolution of supply chain management theory is driven by rapid changes in global business practice. One of the most important practices of the supply chain is managing resources. Goffin et al., (1997) have stated that supplier management is one of the key issues of supply chain management because the cost of raw materials and component parts constitutes the main cost of a product and most of the firms have to spend considerable amount of their sales revenues on purchasing. Ghodsypour and O'Brien (2001) also agreed that selecting the right supplier significantly reduces the purchasing costs and improves corporate competitiveness. In most industries the cost of raw materials and component parts constitutes the main cost of a product, such that in some cases it can account for up to $70 \%$ of the cost (Ghobadian et al., 1993). Therefore, the success of a supply chain is highly dependent on selection of

\footnotetext{
* Corresponding author
} 
good suppliers. A suitable supplier must supply high quality materials, deliver proper quantities of materials at proper time, reduce cost, and provide excellent services in order to satisfy what the buyer requires (Guo-Dong et al., 2008).

The way to evaluate supplier qualification is the main scope of supplier selection. Firms do not have any direct control over the capability and performance of their hundreds or thousands of suppliers. However, the evaluation of their suppliers' qualifications to provide raw materials/ services is a crucial issue to firms. Furthermore, firms should analyse and evaluate the potential threats when selecting suitable suppliers resulting from a systematic selection process and its corresponding attributes. In fact, the decision related to supplier partner selection are complicated by the fact that various criteria must be considered in the decision making process. Although there is a large number of reported studies' addressing the decision criteria to be used for the supplier selection process, nevertheless, this rich literature did not address the need to include the criteria related to behaviour, which have become extremely important. Their exclusion in the evaluation process could result in selection of some inappropriate suppliers whom negative impacts on the firm could be drastic. Unexpectedly, such researches on how companies evaluate and select suppliers including behavioural aspects are rare (Chan and Kumar, 2007).

In this paper, we propose a dynamic multi-period approach for multi-criteria supplier selection and evaluation, which integrates the functional and behavioural aspects. Through this approach, suppliers are selected using AHP through five general criteria (Quality, delivery, price/cost, manufacturing capabilities and management). After a period of time $(\Delta)$, the behaviour of suppliers will be evaluated based on the same criteria that have been used in the process for selection. The process is repeated periodically. The behavioural evaluation is a continues process, while selection is used when the need arises after rejection of some suppliers due to bad behaviour or expansion strategy.

The rest of the paper is organized as follows. Section 2 illustrates some issues observed in the supplier selection processes by reviewing the most important existing studies. Section 3 discusses the behavioural criteria for selecting suppliers. Section 4 presents the multi-period selection and evaluation model. Section 5 provides an illustrative example and section 6 concludes the paper.

\section{Supplier selection approaches and criteria}

\subsection{Supplier selection criteria}

The success of a supply chain is highly dependent on selection of good suppliers. Since price has traditionally been a leading factor, selecting suppliers based on cost has been a common approach. The total cost of working with each supplier is calculated and the cheapest one is selected. Timmerman (1986) proposes cost-ratio method which collects all costs related to quality, delivery, and services and shows them as a benefit or penalty percentage on unit price.

Yet, simply looking for vendors offering the lowest prices is not efficient sourcing any more (Ellram, 1990). Multiple criteria need to be taken into account when selecting suppliers. (Talluri and Narasimhan, 2001). In academic research and literature, there are a numbers of supplier selection methods all of which use different criteria to select and evaluate suppliers. Early in 1966, Dickson made a conceptual study where he identified 23 criteria to evaluate the suppliers. Lehmann and O’Shaughnessy (1982) proposed 5 criteria: performance, economy, plenitude, agreements and social norms. Caddick and Dale (1987) referred that quality, production plan, control system validity, historic activity, item category and price must be included in the criteria. A latter review by Weber $e t$ al., (1991) based on 74 related papers reported that well over half of the papers reviewed addressed the supplier selection problem with multiple criteria and concluded that quality was the most important criterion followed by delivery and cost performance. Patton (1996) proposed 7 criteria: price, quality, delivery, sales support, equipment, technology, order process and supplier company financial position. Mandal and Deshmukh (1994) developed an analytical framework, which combines qualitative and quantitative factors. A study by Vokurka et al., (1996) proposed different categories of criteria which are performance, economic, integrative and adaptive criteria. Last review 
by William et al., (2010) proves that the traditional cost-based approach cannot guarantee that the selected supplier is global optimal because the customer-oriented criteria (quality, delivery, flexibility, and so on) were not considered.

\subsection{Methods of supplier selection}

In the literature, there are many studies about the supplier selection process. Traditional methodologies of the supplier selection process in research literature include the cost-ratio method, the categorical method, weighted-point evaluations, mathematical programming models and statistical (probabilistic) approaches (Yan et al., 2003; Oliveira and Lourenco, 2002; Weber and Current, 1993).

Considering the problem of supplier selection that has several objectives, AHP is widely used in studies related to categorical methods since it is one of the extensively used multi-criteria decisionmaking methods (Akarte et al., (2001); Muralidharan et al., (2002); Chan (2003); Chan and Chan (2004); Liu and Hai (2005); Chan et al., (2007); Hou and Su (2007); Handfield et al., (2002). The AHP method was introduced by Thomas L. Saaty (1980) is effectively handles both qualitative and quantitative data in decision making problems and its process is easy to understand. Ghodsypour and O'Brien (1998) proposed an integration of AHP and linear programming to consider both tangible and intangible factors in choosing the best suppliers and placing the optimum order quantities among them. Çebi and Bayraktar (2003) structure the supplier selection problem as an integrated lexicographic goal programming and AHP model including both quantitative and qualitative conflicting factors. Wang et al., (2004) use AHP and preemptive goal programming based multicriteria decision-making methodology is then developed to take into account both qualitative and quantitative factors in supplier selection. Wang and Yang (2009) search supplier selection in a quantity discount environment using multi objective linear programming, AHP, and fuzzy compromise programming.

\subsection{The role of behavioural aspects in supplier selection and evaluation}

In reality, the future behaviours of the suppliers are uncertain. Consequently, it is difficult to predict any supplier behaviour nether less assign a fixed mark for their criterion selection. Though, it is more practical to point out some scenarios that describe the probabilistic behaviour of suppliers using simulation. However, it is unfeasible to cover all possible situations for suppliers in the supply chains, where efficient analysis can be a challenging issue to come with a solution (Jain et al., 2009). Infact, selection of suppliers based on their factual behaviour has not been well studied in literature. Past studies employ multiple terms to identify the conduct of suppliers who could behave in a manner that is contrary to the expectations of the organization and broader common norms. (Jafar and Roland, 2013) argue that in supplier selection, all criteria can be categorised under two dimensions (supplier capabilities and supplier willingness) in order to predict suppliers future behaviour. However, using "willingness" criteria for selection may not unravel the uncertainty for supplier behaviour.

The strategic nature of the supplier selection decision determines the necessity of studying suppliers' behaviour prior final selection. However, the majority of the existing models/approaches/methods are based on functional criteria like quality, price, delivery time, etc., and do not incorporate the behavioural aspects of the suppliers as a part of the selection process. Furthermore, theses studies do not implement a dynamic system of evaluation right after selection.

\section{Incorporating behavioural criteria in supplier selection}

Selecting the suitable suppliers is always a difficult task for firms. Suppliers have varied strengths and weaknesses, which require careful assessment by the firm before ranking can be made. The objective of supplier selection is to identify suppliers with the highest potential for meeting a 
firm's needs consistently and at an acceptable cost. Selection is a broad comparison of suppliers using a common set of criteria and measures. However, the level of detail used for examining potential suppliers may vary depending on a firm's needs and the established goals.

Supplier behaviour, in this presented approach can be viewed as a sub-process of supplier selection process to resolving supplier choice problems. Behavioural analysis assumes that if the supplier engages in a number of preparatory behaviours prior to final selection, the trial will be more likely to result in an unfavourable outcome. The supplier selection process major task is to dynamically prevent such supplier behaviours. The behavioural analysis can promote the competition among suppliers and furthermore help to demonstrate the real utility of evaluation. The incorporation of the behavioural aspects leads to resolve supplier selection problems in dynamic and rational way. In addition, it saves firms time, efforts and especially potential loss and disruption of the supply chain management which in return will affect the entire firm negatively.

Through literature, mainly the review, mainly of William et al., (2010), we could find some criteria that could be adequate to evaluating behavioural aspects of suppliers. A list provided in Table 1.

Table 1. A list of behavioural criteria.

\begin{tabular}{|c|c|}
\hline Criteria & Authors \\
\hline $\begin{array}{l}\text { Number of shipments to arrive on time; Number of bills received from } \\
\text { the supplier without errors; Service quality experience; Service quality } \\
\text { credence. }\end{array}$ & Talluri and Sarkis (2002) \\
\hline $\begin{array}{l}\text { Percentage of order acknowledgements with a promise ship date } \\
\text { within } 24 \text { hrs of PO issue; Percentage of suppliers shipping notices } \\
\text { received at buyer within } 24 \text { hrs of ship date; Percentage of orders } \\
\text { shipped to buyer on or before the original promised ship date; } \\
\text { Percentage of orders shipped on or before final ship date; Percentage } \\
\text { of orders delivered by the due date; Percentage of products/items not } \\
\text { rejected upon inspection. }\end{array}$ & Ross et al. (2006) \\
\hline $\begin{array}{l}\text { Compliance with due date; Compliance with quality; Rejection in } \\
\text { incoming quality; Rejection in production line; Quality system and } \\
\text { implementation; Response time; Technical competence; Product } \\
\text { development time; Product innovation; Cultural innovation. }\end{array}$ & Choy et al. (2003a) \\
\hline $\begin{array}{l}\text { Rejection from customers; Product development time; Use of the } \\
\text { Internet. }\end{array}$ & Choy et al. (2003b) \\
\hline $\begin{array}{l}\text { Handling; Use in manufacturing; Other business consideration; End } \\
\text { use; Follow up; Customer support; Customer satisfiers; } \\
\text { Professionalism. }\end{array}$ & Kahraman et al. (2003) \\
\hline $\begin{array}{l}\text { Capacity for innovation to follow up the customer's evolution in terms } \\
\text { of changes in its strategy and market; Flexibility of response to the } \\
\text { customer's requests; Ability to manage orders on-line. }\end{array}$ & Bevilacqua et al. (2006) \\
\hline $\begin{array}{l}\text { Conformance quality; Flexibility; Delivery reliability; Technical } \\
\text { capability; Continuous improvement programs; Technical information } \\
\text { sharing; Product innovation capabilities; Financial strength; } \\
\text { Management skills; Long-term relationship; Response to complaints; } \\
\text { Warranty support. }\end{array}$ & Perçin (2006) \\
\hline $\begin{array}{l}\text { Cash-to-cash cycle time; Inventory days of supply; Production } \\
\text { flexibility; Quality performance; Value-added productivity; Supply } \\
\text { chain response time; Delivery lead time; Fill rate. }\end{array}$ & Chen and Huang (2007) \\
\hline $\begin{array}{l}\text { Shipment quality; Inspection and control; Quality assurance; } \\
\text { Production capacity; Maintenance; Lead-time; Up to date; Patent; } \\
\text { Technical capability. }\end{array}$ & Sevkli et al. (2007) \\
\hline $\begin{array}{l}\text { Technical level; Defects; Reliability; On-time delivery; Supply } \\
\text { capacity; Repair turnaround time; Warranty period. }\end{array}$ & Xia and Wu (2007) \\
\hline $\begin{array}{l}\text { Low defect rate; On-time delivery; Process flexibility; Response to } \\
\text { changes; Support to design process; Consistency; Mutual trust and }\end{array}$ & Demirtas and Üstün (2008) \\
\hline
\end{tabular}


ease of communication; Unit cost; Break in line; Measurement and assessment; Order delays; Customer complaints; Inability to meet further requirements.

\section{Model construction:}

In order to enhance the previous supplier selection methods by automating the decision making process in the areas of supplier selections, a behavioural aspects have been integrated using (AHP). The proposed model consists of two processes, the selection of new suppliers' process and the behavioral evaluation of existing ones. The behavioral evaluation process is periodical, while the selection process is activated when necessary. For the sake of simplicity, the model is presented in six major steps for supplier selection and evaluation. See figure 1. For the selection and evaluation of suppliers, the company decides on the period of time $\Delta$ for periodical evaluation and decision on the status of existing suppliers (reject or keep).

Step 1: The process started at $t=0$ with two sets of suppliers: the list of existing suppliers and; the list of potential new suppliers. The collection of information on behaviour of existing suppliers starts, and this process is a continuous process.

In case there is no need for selection of new suppliers in the time period $\Delta$ go to step 4. Otherwise, new supplier selection starts.

Step 2: The potential new suppliers are evaluated and ranked based on the selected criteria and AHP method.

Step 3: An update of the list of existing suppliers is made based on the results of step 2. The accepted suppliers will join the chain for probation.

If $\mathrm{t} \leq \Delta$ then, they wait until the end of period $\Delta$.

Step 4: Set $\mathrm{t}=\mathrm{t}+\Delta$, select the criteria for behavioural evaluation then start the behavioural evaluation of suppliers using AHP.

Step 5: As a result of step 4, a decision is made about the status of each existing supplier, some suppliers may be rejected because of poor performance. Therefore, the list of existing suppliers has to be updated. The rejection of suppliers should not be immediate. The firm should take enough time for replacement to avoid disturbance in supply.

Step 6: In case the firm needs new suppliers because of an expected lack of new suppliers that may result from step 5, the firm needs to update the list of potential new suppliers, then go to step 2. Otherwise when $t$ reaches $t+\Delta$, go to step 4 . 
Figure 1. Suppliers' selection and evaluation process

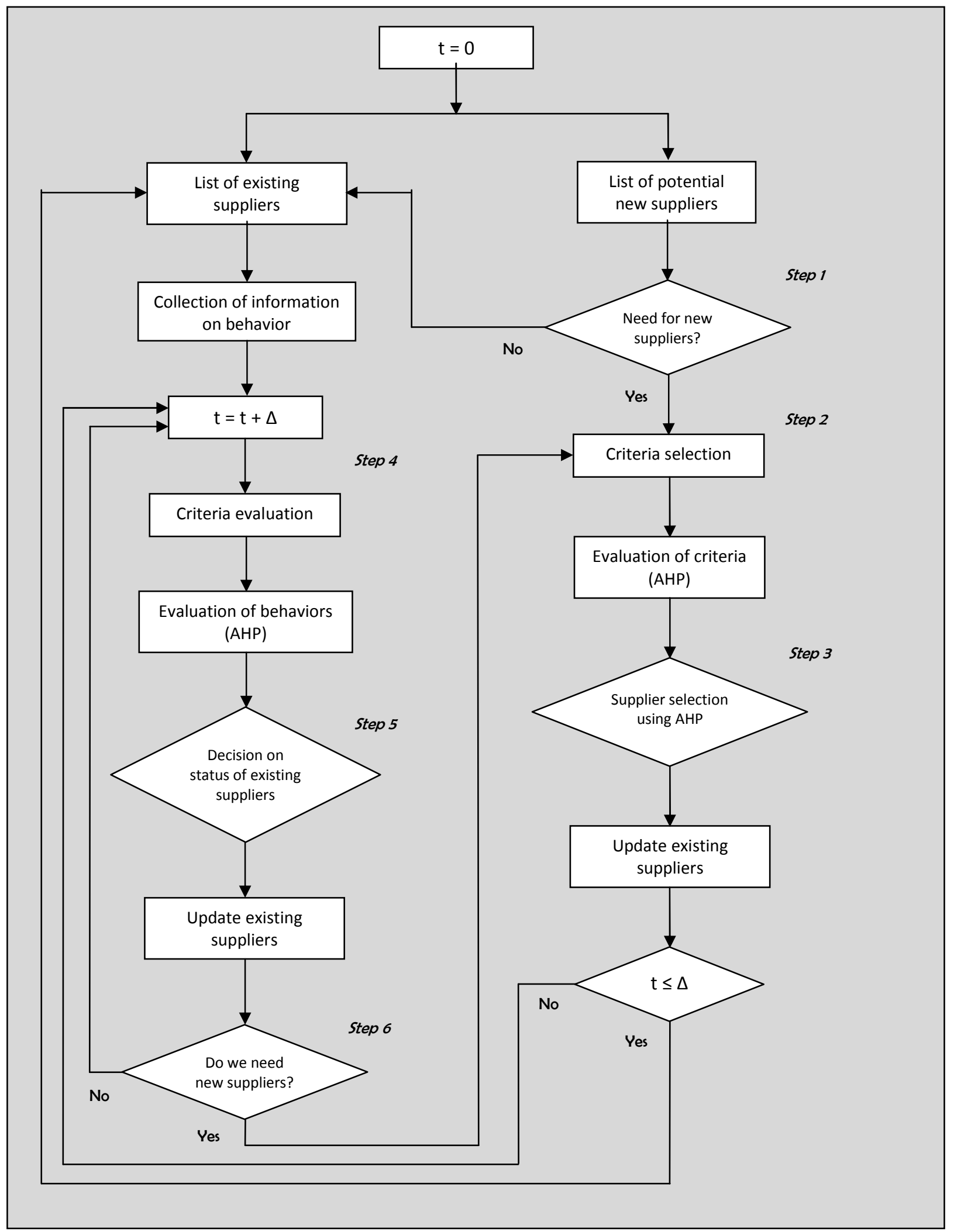




\section{AHP application to the process: An illustrative case:}

The management of a manufacturing company $\mathrm{X}$, which is a global leader in design, production, and marketing of communication systems wants to expand and to involve new suppliers to its supply chain. In order to meet its goals, Company $\mathrm{X}$ has placed emphasis on supplier rationalization by selecting new suppliers and evaluating existing ones for long and short terms scale, providing continuous feedback for improving performance, achieving excellence across multiple competitive dimensions, and decreasing supply by pruning inefficient suppliers. As discussed earlier, our framework specifically addresses these issues. The company has three existing suppliers and three potential suppliers.

Let us start implementing the introduced model in section 4 following the steps $1-6$. We assume that the company has fixed the evaluation period as $\Delta=2$ months.

Let $\Omega=\{\mathrm{A}, \mathrm{B}, \mathrm{C}\}$ be the set of existing suppliers, and let $\beta=\{\mathrm{D}, \mathrm{E}, \mathrm{F}\}$ be the set of potential suppliers.

Step 1: The process starts at $\mathrm{t}=0$, the collection of information on existing suppliers starts.

Does the company want to select new suppliers? Yes, as we mentioned above, the company $\mathrm{X}$ is willing to select new suppliers.

Step 2: The company chooses the criteria, weight scores of the criteria and sub criteria to evaluate the new suppliers' qualification. Five major criteria were considered for supplier selection. See Table 2.

Table 2. Qualification and behavioural criteria and sub-criteria

\begin{tabular}{|c|c|c|}
\hline Criteria & Qualification sub-criteria & Behavioural sub-criteria \\
\hline Quality (Q) & $\begin{array}{l}\text { - Product Quality (EQ1) } \\
\text { - Operational controls (EQ2) }\end{array}$ & $\begin{array}{l}\text { - Rejection in incoming quality (BQ1) } \\
\text { - Supplier's effort in eliminating waste (BQ2) }\end{array}$ \\
\hline Delivery (D) & $\begin{array}{l}\text { - Geographic location (ED1) } \\
\text { - Reserve capacity (ED2) }\end{array}$ & $\begin{array}{l}\text { - Order delays (BD1) } \\
\text { - Inability to meet further requirements (BM2) }\end{array}$ \\
\hline Cost $(C)$ & $\begin{array}{l}\text { - Product cost (EC1) } \\
\text { - Payment flexibility (EC2) }\end{array}$ & $\begin{array}{l}\text { - Profit impact of supplier (BC1) } \\
\text { - Cash-to-cash cycle time (BC2) }\end{array}$ \\
\hline $\begin{array}{l}\text { Manufacturing } \\
\text { Capabilities (B) }\end{array}$ & $\begin{array}{l}\text { - manufacturing facilities \& capacity } \\
\text { (EM1) } \\
\text { - Technology monitoring (EM2) }\end{array}$ & $\begin{array}{l}\text { - Low defect rate (BM1) } \\
\text { - Repair turnaround time (BM2) }\end{array}$ \\
\hline $\begin{array}{l}\text { Management } \\
\text { (M) }\end{array}$ & $\begin{array}{l}\text { - Performance award (EM1) } \\
\text { - After sales support (EM2) }\end{array}$ & $\begin{array}{l}\text { - Response to complains (BM1) } \\
\text { - Consistency and follow-through (BM2) }\end{array}$ \\
\hline
\end{tabular}

Step 3: The new suppliers are evaluated based on AHP method; the five criteria were measured with a composite scale between 1 and 9 for comparing suppliers. The scales are explained in Table 3.

Table 3. AHP's values scale (Saaty, 2005)

\begin{tabular}{|c|l|l|}
\hline $\begin{array}{c}\text { Intensity of } \\
\text { Importance }\end{array}$ & \multicolumn{1}{|c|}{ Definition } & \multicolumn{1}{c|}{ Explanation } \\
\hline 1 & Equal importance & Two activity contribute equality to the objective \\
\hline 2 & Weak & Experience and judgment slightly favour one activity over another \\
\hline 3 & Moderate importance & Experience and judgment strongly favour one over another \\
\hline 4 & Moderate plus \\
\hline 5 & Strong importance & \\
\hline 6 & Strong plus & $\begin{array}{l}\text { An activity is favoured very strongly over another; dominance } \\
\text { demonstrated in practice }\end{array}$ \\
\hline 7 & $\begin{array}{l}\text { Very strong or } \\
\text { demonstrated importance }\end{array}$ \\
\hline
\end{tabular}




\begin{tabular}{|l|l|l|}
\hline 8 & Very, very strong \\
\hline 9 & Extreme importance & $\begin{array}{l}\text { The evidence favouring one activity over another is of the highest } \\
\text { possible order of affirmation }\end{array}$ \\
\hline
\end{tabular}

The results identified suppliers D and E to be more qualified than the other supplier F. These results are shown in Table 4.

Table 4. The evaluation of new suppliers' qualification

\begin{tabular}{|l|c|c|c|c|c|c|c|c|c|l|l|}
\hline Alternative & FQ1 & FQ2 & FD1 & FD2 & FC1 & FC2 & FB1 & FB2 & FM1 & FM2 & Priority \\
\hline Supplier D & .145 & .035 & .043 & .023 & .065 & .014 & .029 & .011 & .013 & .017 & .396 \\
\hline Supplier E & .092 & .041 & .086 & .020 & .045 & .008 & .017 & .009 & .043 & .013 & .374 \\
\hline Supplier F & .115 & .012 & .022 & .007 & .016 & .003 & .020 & .002 & .024 & .010 & .231 \\
\hline
\end{tabular}

As a result, the set of existing suppliers is updated $\Omega=\{\mathrm{A}, \mathrm{B}, \mathrm{C}, \mathrm{D}, \mathrm{E}\}$. Suppliers D and E joined the supply chain for probation. During this period, the behavioural aspects of the suppliers are under-evaluation and data were collected and quantified.

If $\mathrm{t} \leq \Delta$ wait until $\mathrm{t}=\Delta$, then go to step 4 .

Step 4: $\mathrm{t}=\mathrm{t}+\Delta$, for simplicity of presentation we assume that the company $\mathrm{X}$ takes the evaluation of criteria as the selection criteria of step 2. See Figure 2.

Figure 2. supplier selection hierarchy




Table 5. suppliers' behavioural evaluation

\begin{tabular}{|l|l|l|l|l|l|l|l|l|l|l|l|l|}
\hline Alternatives & FQ1 & FQ2 & FD1 & FD2 & FC1 & FC2 & FB1 & FB2 & FM1 & FM2 & FM2 & Total \\
\hline Supplier A & .521 & 1.000 & 1.000 & 1.000 & 1.000 & 1.000 & 1.000 & 1.000 & .866 & 1.000 & 1.000 & .236 \\
\hline Supplier B & .512 & .989 & .801 & .839 & .759 & .358 & .672 & .622 & 1.000 & .610 & .610 & .203 \\
\hline Supplier C & .510 & .545 & .788 & .644 & .444 & .325 & .765 & .404 & .451 & .481 & .481 & .163 \\
\hline Supplier D & .795 & .595 & .575 & .540 & .382 & .393 & .672 & .632 & .608 & .682 & .682 & .189 \\
\hline Supplier E & 1.000 & .712 & .274 & .444 & .827 & .435 & .773 & .421 & .616 & .594 & .594 & .209 \\
\hline
\end{tabular}

Step 5: Decisions on the status of existing suppliers are taken.

As a result, the set of existing suppliers is updated $\Omega=\{\mathrm{A}, \mathrm{B}, \mathrm{D}, \mathrm{E}\}$. Company $\mathrm{X}$ now is willing to select suppliers A, E, B as main suppliers and D will be held for reserve and reevaluated when needed. Supplier C is taken out the supply chain due to its weak performance. See Table 6.

Table 6. suppliers' ranking

\begin{tabular}{|l|l|}
\hline Alternative & Priority \\
\hline Supplier A & .236 \\
\hline Supplier E & .209 \\
\hline Supplier B & .203 \\
\hline Supplier D & .189 \\
\hline Supplier C & .163 \\
\hline
\end{tabular}

Step 6: Does the company need new suppliers? If No, go to step 4. If Yes, go to step 2.

It can be concluded that supplier $\mathrm{A}$ is the best performer with a score of 0.236 , and supplier $\mathrm{C}$ is the worst performer with a score of 0.163 . It is interesting to note that supplier $\mathrm{D}$, which is efficient based on the first AHP model evaluations, is ranked very high based on functional evaluations with a mean score of 0.396. In fact some of the low ranked suppliers such as E, and B are better in behaviour performers than supplier D based on cross-efficiency evaluations. Supplier E is a typical case of the importance of this model. The supplier E, with an efficiency score of 0.374, achieved a crossefficiency behavioural mean score of 0.209 , which is higher than high ranked suppliers B, D, and C. These insights and differentiation among suppliers are not possible when using the functional model alone, which demonstrates the strength of behavioural evaluations as a more comprehensive technique for efficiency evaluation. It is essential for the decision-maker to consider these issues in supplier rationalization in order to avoid misjudgement in the next selection process.

It should be noted that quantitative behavioural criteria are easier to evaluate than qualitative criteria which require subjective judgement. Hence, this acts as a filtering process to eliminate those suppliers who do not meet the quantitative benchmarks established by the company.

To this end, we have performed one iteration of the process. In the next iteration the process is repeated.

The advantages of this method for supplier selection are:

1) Reduce the time and effort in selecting the best available suppliers. It also reduces any potential risk that could emerge from suppliers' behaviours

2) Reduction of the uncertainty when dealing with suppliers' selection since the method is based on previous and actual behaviour of suppliers. 
3) Corporate strategies can be reflected in purchasing activities.

4) Using real data, the calculation is simplified and the system's consistency is improved.

5) Using AHP reduce human judgement error on imprecision.

\section{Conclusion:}

This paper proposed a unique approach for supplier selection by incorporating behavioural criteria into the selection and evaluation process. The approach for supplier selection presented in this paper allows for comprehensive and dynamic evaluation of suppliers based on their behaviours for a period of time set by the firm. This method would certainly enhance the process of selection and evaluation suppliers by incorporates their past behaviour.

The limitation of this article is that AHP ignores the uncertainty of executives' judgment during the decision-making process. In such cases, fuzzy numbers can be used to obtain the evaluation matrix, and the proposed model can be enlarged by using fuzzy numbers. Another direction of future research will probably be on a more soft side. The choice of a hierarchy and a judgement scale is important and difficult. Problem structuring methods could help in the construction of AHP hierarchies. The application of this method in a real world setting needs to be further investigated. Some of the potential issues that managers may encounter are selection of appropriate input and output factors, number of factors, incorporation of firm's targets and strategies into the evaluation process.

\section{References}

Akarte, M.M., Surendra, N.V., Ravi, B. and Rangaraj, N. (2001), "Web based casting supplier evaluation using analytical hierarchy process", Journal of the Operational Research Society, 52 (5), 511-522.

Bevilacqua, M., Ciarapica, F.E. and Giacchetta, G. (2006), "A fuzzy-QFD approach to supplier selection", Journal of Purchasing and Supply Management, 12 (1), 14-27.

Caddick, J.R. and Dale, B.G. (1987), "Sourcing from less developed countries: a case study", Journal of Purchasing and Materials Management, 23 (3), 17.

Cebi, F. and Bayraktar, D. (2003), "An integrated approach for supplier selection", Logistics Information Management. 16(6), 395-400.

Chan, F.T.S. (2003), Interactive selection model for supplier selection process: An analytical hierarchy process approach. International Journal Production Research, 41 (15), 3549-3579.

Chan, F.T.S. and Chan, H.K. (2004), "Development of the supplier selection model - A case study in the advanced technology industry, Proceedings of the Institution of Mechanical Engineers Part B", Journal of Engineering Manufacture. 218 (12), 1807-1824.

Chan, F.T.S. and Kumar, N. (2007), "Global supplier development considering risk factors using fuzzy extended AHP-based approach", Omega - International Journal of Management Science, 35 (4), 417-431.

Chen, Y.M. and Huang, P.N. (2007), "Bi-negotiation integrated AHP in suppliers selection", Benchmarking: An International Journal, 14 (5), 575-593.

Choy, K.L., Lee, W.B. and Lo, V. (2003a), "Design of a case based intelligent supplier relationship management system - The integration of supplier rating system and product coding system", Expert Systems with Applications, 25 (1), 87-100.

Choy, K.L., Lee, W.B. and Lo, V. (2003b), "Design of an intelligent supplier relationship management system: A hybrid case based neural network approach", Expert Systems with Applications, 24 (2), 225-237.

Demirtas, E.A. and Ustun, O. (2008), "An integrated multi-objective decision making process for supplier selection and order allocation", Omega - International Journal of Management Science, 36 (1), 76-90. 
Dickson, G. (1966), "An analysis of vendor selection systems and decisions", Journal of Purchasing, $2,28-41$.

Ellram, L. M. (1990), "The supplier selection decision in strategic partnerships", Journal of Purchasing and Materials Management, 26(4), 8-14.

Ghodsypour, S. H. and O'Brien, C. (1998), "A decision support system for supplier selection using an integrated analytical hierarchy process and linear programming", International Journal of Production Economics. (56/57), 199-212.

Ghodsypour, S. H. and O'Brien, C. (2001), "The total cost of logistics in supplier selection, under conditions of multiple sourcing, multiple criteria and capacity constraint", International Journal of Production Economics, 73, 15-27.

Ghobadian, A., Stainer, A. and Kiss, T. (1993), "A computerized vendor rating system. In Proceedings of the first international symposium on logistics", The University of Nottingham, Nottingham, UK. 321-328.

Goffin, K., Szwejczewski, M., \& New, C. (1997), "Managing suppliers: When fewer can mean more", International Journal of Physical Distribution \& Logistics Management, 27(7), 422-436.

Guo-Dong, L., Shiro, M., Daisuke, Y., Masatake, N. and Chen-Hong, W. (2008), "A study on the prediction of machining accuracy", The International Journal of Advanced Manufacturing Technology, 43(5-6).

Handfield, R., Walton, S. V., Sroufe, R. and Melnyk, S. A. (2002), "Applying environmental criteria to supplier assessment: A study in the application of the Analytical Hierarchy Process", European Journal of Operational Research, 141, 70-87.

Harland, C.M., Lamming, R.C. and Cousins, P.D. (1999), "Developing the concept of supply strategy". International Journal of Operations and Production Management, 19, 650-673.

Hou, J. and Su, D. (2007), "EJB-MVC oriented supplier selection system for mass customization", Journal of Manufacturing Technology Management, 18 (1), 54-71.

Jafar, R. and Roland, O. (2013), "Multi-criteria supplier segmentation using a fuzzy preference relations based AHP", European Journal of Operational Research, 225(1), 75-84.

Jain, V., Wadhwa, S. and Deshmukh, S.G. (2009), "Select supplier-related issues in modelling a dynamic supply chain: potential, challenges and direction for future research", International Journal of Production Research, 47 (11), 3013-39.

Kahraman, C., Cebeci, U. and Ulukan, Z. (2003), "Multi-criteria supplier selection using fuzzy AHP", Logistics Information Management, 16(6), 382-394.

Lehmann, D.R and O'Shaughnessy, J. (1982), "Decision criteria used in buying different categories of products", Journal of Purchasing and Materials Management, (18), 9-14.

Liu, F.H.F. and Hai, H.L. (2005), "The voting analytic hierarchy process method for selecting supplier", International Journal of Production Economics, 97 (3), 308-317.

Mandal, A. and Deshmukh, S.G. (1994), "Vendor selection using interpretative structural modelling (ISM) ", International Journal of Operations and Production Management, 14 (6), 52-59.

Muralidharan, C., Anantharaman, N. and Deshmukh, S.G. (2002), "A multi-criteria group decisionmaking model for supplier rating", Journal of Supply Chain Management, 38 (4), 22-33.

Oliver, R. K. and Webber, M. D. (1992), "Supply-chain management: Logistics catches up with strategy. In Christopher, M. (Ed.), Logistics: The strategic issues", Chapman \& Hall, London UK, 63-75.

Oliveria, R. C. and Lourenco, J. C. (2002), "A multicriteria model for assigning new orders to service suppliers", European Journal of Operational Research, 139, 390-399.

Patton, W. E. (1996), "Use of human judgment models in industrial buyers' vendor selection decisions", Industrial Marketing Management, 25, 135-149.

Perçin, S. (2006), "An application of the integrated AHP-PGP model in supplier selection", Measuring Business Excellence, 10 (4), 34-49.

Ross, A., Buffa, F.P., Droge, C. and Carrington, D. (2006), "Supplier evaluation in a dyadic relationship: An action research approach", Journal of Business Logistics, 27 (2), 75-102.

Saaty, T. L. (1980), "The analytic hierarchy process", New York: McGraw-Hill.

Saaty, T. L. (1990), "How to make a decision: The analytic hierarchy process", European Journal of Operational Research, 48, 9-26. 
Saaty, T. (2006), "Rank from Comparisons and from Ratings in the Analytic Hierarchy/Network Processes", European Journal of Operational Research, 168(2), 557-570.

Sevkli, M., Koh, S. C. L., Zaim, S., Demirbag, M. and Tatoglu, E. (2007), "An application of data envelopment analytic hierarchy process for supplier selection: A case study of BEKO in Turkey", International Journal of Production Research, 45(9),1973-2003.

Talluri, S. and Narasimhan, R. (2001), "Vendor evaluation with performance variability: A max-min approach", European Journal of Operational Research. 146 (3), 543-552.

Talluri, S. and Sarkis, J. (2002). "A model for performance monitoring of suppliers", International Journal of Production Research, 40 (16), 4257-4269.

Timmerman, E. (1986), "An approach to vendor performance evaluation", Journal of Purchasing and Materials Management, 22(4), 2-9.

Vokurka, R. J., Choobineh, J. and Vadi, L. (1996), "A prototype expert system for the evaluation and selection of potential suppliers", International Journal of Operations \& Production Management, 16 (12), 106-127.

Wang, G., Huang, S. H., and Dismukes, J. P. (2004), "Product-driven supply chain selection using integrated multi-criteria decision-making methodology", International Journal of Production Economics, 91, 1-15.

Wang, T.-Y., and Yang, Y.-H. (2009), "A fuzzy model for supplier selection in quantity discount environments", Expert Systems with Applications, 36(10), 12179-12187.

Weber, C. A., Current, J. R. and Benton, W. C. (1991), "Vendor selection criteria and methods". European Journal of Operational Research, 50, 2-18.

Weber, C.A. and Current, J.R. (1993), "A multiobjective approach to vendor selection", European Journal of Operational Research, 68, 173-184.

William, H., Xiaowei, X. and Prasanta K. D. (2010), "Multi-criteria decision making approaches for supplier evaluation and selection: A literature review", European Journal of Operational Research, 202, 16-24.

Xia, W. and Wu, Z. (2007), "Supplier selection with multiple criteria in volume discount environments". Omega - International Journal of Management Science, 35 (5), 494-504.

Yan, H., Yu, Z., \& Cheng, T. C. E. (2003), "A strategic model for supply chain design with logical constraints: Formulation and solution". Computers and Operations Research, 30, 2135-2155. 